\title{
ALK Protein Measurement
}

National Cancer Institute

\section{Source}

National Cancer Institute. ALK Protein Measurement. NCI Thesaurus. Code C154805.

The determination of the amount of ALK protein present in a sample. 